\title{
Partisipasi Organisasi Keagamaan Dalam Penyiaran Dakwah Islam di Kota Langsa
}

\section{(The Participation of Religious Organizations in Broadcasting Islamic Da'wah in Langsa City)}

\author{
Mawardi Siregar \\ Program Studi Komunikasi dan Penyiaran Islam, Institut Agama Islam Negeri Langsa, Indonesia \\ email: sipirokpbujur76@gmail.com
}

\begin{abstract}
First received:
7 November 2021

Revised:
December 2021

Final Accepted:

12 December 2021

ABSTRACT

A society that continues to develop and change is definitely a challenge for religious organizations. Facing the reality of these changes, da'wah organizations are required to present da'wah in a professional and qualified manner, to defend society from the penetration of modernism which threaten the fundamentals of religious teacbings. Current article intents to discuss the participation of religious organizations in broadcasting Islamic da'wah in Langsa City. Using qualitative research, data were collected through in-depth interviens with purposively selected participants, and continuously observing da'wah activities carried out by religious organizations in Langsa City. At the beginning of this paper, the social and religious dynamics of the people of Langsa City are described. The next section described the participation of religious organizations in broadcasting da'wah in Langsa City. This article argues that the broadcasting of da'wab carried out by religious organizations bas not been maximized. In addition, it is essential for religious organizations to plan a da'wah scheme relevant to the development of the Langsa City community, thus the da'wah carried out appealing in empowering the community religious potential.
\end{abstract}

Keywords : Participation; Religious Organization; Da'wa; Langsa City.

\section{ABSTRAK}

Masyarakat yang terus berkembang dan berubah tentu menjadi tantangan bagi organisasi keagamaan. Menghadapi realitas perubahan tersebut, organisasi dakwah dituntut untuk mengemas dakwah secara profesional dan berkualitas, sehingga dapat menjaga masyarakat dari serbuan modernisme yang dapat meruntuhkan sendi-sendi ajaran agama. Artikel ini bertujuan untuk membahas partisipasi organisasi kemasyarakatan dalam penyiaran dakwah Islam di Kota Langsa. Menggunakan penelitian kualitatif, data dikumpulkan melalui wawancara mendalam dengan informan yang telah dipilih secara purposive, dan mengamati secara berkesinambungan aktivitas dakwah yang dilakukan organisasi keagamaan di Kota Langsa. Pada bagian awal tulisan ini dipaparkan dinamika sosial dan keberagamaan masyarakat kota langsa. Pada bagian selanjutnya dipaparkan partisipasi organisasi keagamaan dalam penyiaran dakwah di Kota Langsa. Tulisan ini berargumen, bahwa penyiaran dakwah yang dilakukan oleh organisasi keagamaan belum maksimal. Selain itu, organisasi keagamaan sangat penting merancang satu formula dakwah yang relevan dengan perkembangan masyarakat Kota Langsa, agar dakwah yang dilakukan memiliki daya tarik dalam memberdayakan potensi keagamaan masyarakat.

Kata kunci : Partisipasi; Organisasi Keagamaan; Dakwah; Kota Langsa.

\section{PENDAHULUAN}

Artikel ini mengeksplorasi parsitisipasi organisasi keagamaan dalam penyiaran dakwah di Kota Langsa. Dalam waktu yang sudah cukup lama, peran organisasi keagamaan dianggap amat sangat penting dalam penyebaran penyiaran dakwah Islam. Tidak hanya karena didasarkan pada perintah Allah Swt dalam Al Qur'an Surah Ali Imran 104, kehadiran organisasi keagamaan dapat menyemarakkan gerakan dakwah Islam. Organisasi keagamaan memiliki 
potensi yang sangat kuat dalam penyiaran dakwah Islam, seperti yang dilakukan oleh NU, Muhammadiyah dan organisasi keagamaan lainnya (Suprayogo, 2008).

Kehadiran lembaga keagamaan menambah khazanah atau pengayaan dalam penyiaran dakwah Islam. Selama ini frekuensi penyiaran dakwah Islam banyak dilakukan oleh da'i secara perorangan. Tetapi seiring dengan munculnya organisasi keagamaan, kegiatan dakwahpun mulai bergeser dari personal kepada komunal. Aktivitas dakwah banyak dilakukan para pendakwah secara berjamaah melalui program organisasi yang terstruktur dan terprogram secara rapi. Organisasi-organisasi keagamaan muncul dengan warna dan model gerakan yang bervariasi, namun pada prinsipnya tujuannya untuk menanamkan kesaadaran beragama, sehingga terwujud kebahagiaan dunia dan akhirat.

Kesadaran untuk mengamalkan ajaran agama, tidak akan tercapai jika diantara kaum muslimin tidak saling menasehati. Di sinilah perlu adanya kegiatan dakwah, sehingga ajaran Islam itu dapat dikomunikasikan kepada umat secara berkesinambungan. Ketika masa Nabi Muhammad Saw, sahabat dan tabi'in sudah berlalu, maka kewajiban berdakwah menjadi tanggung jawab setiap muslim yang hidup di zaman ini. Namun sangat perlu disadari, bahwa kegiatan dakwah merupakan kegiatan yang menuntut profesionalisme, sehingga dituntut kemampuan khusus untuk melaksanakannya. Selain memiliki keimanan dan ketakwaan yang kuat, wawasan pengetahuan yang luas dan kemahiran berkomunikasi menjadi syarat kompetensi yang harus dimiliki oleh seorang da’i (Kholil, 2007).

Paralel dengan pandangan yang disampaikan oleh Rakhmat (2001), bahwa untuk mempengaruhi komunikan (dalam istilah dakwah disebut mad'u), tidak hanya tergantung pada pesan yang disampaikan. Secara keseluruhan, keadaan komunikator turut menentukan sampainya pesan kepada khalayak. Selain itu, metode yang rapi, teratur dan media yang digunakan juga turut menentukan keberhasilan penyampaian pesan (Abdul, 2001).

Organisasi keagamaan dalam konteks masyarakat yang terus berkembang, turut membantu tugas da'i yang selama ini banyak dilakukan secara personal. Kondisi ini menunjukkan semakin luasnya interaksi agama dengan masyarakat. Senyatanya, selama ini banyak kepentingan umat Islam yang memerlukan fatwa organisasi keagamaan. Tentu fenomena ini menunjukkan semakin meningkatnya keperluan masyarakat terhadap dakwah Islam.

Pada satu sisi, masyarakat informatif tidak mudah untuk diajak dalam kegiatan-kegiatan dakwah, karena suguhan informasi kegamaan sudah amat sangat banyak tersedia di medamedia yang berkembang. Tetapi pada sisi lain, segala dampak yang ditimbulkan oleh kemajuan teknologi, menjadi tantangan bagi organisasi keagamaan untuk merancang strategi dakwah yang relevan. Gerakan dakwah yang dilakukan organisasi keagamaan tidak lagi sekedar memperhatikan persoalan yang muncul pada masyarakat global industrial. Tetapi secara operasional, dakwah yang dilakukan organisasi keagamaan harus menjadi layanan sosial dalam menyelesaikan masalah masyarakat modern. Demikianlah dakwah yang sejatinya menjadi wujud tanggung jawab terhadap kemanusiaan. Rumusan maupun formulasi dakwah yang solutif seharusnya tentu menjadi tawaran organisasi keagamaan sehingga gerakan dakwahnya menjadi pengendali terhadap kehidupan yang manusiawi, dinamis, dan berkemajuan sesuai dengan prinsip dasar ajaran Islam.

Tulisan ini bukan satu-satunya yang membahas partisipasi dakwah organisasi keagamaan bukanlah kajian baru. Sejumlah sarjana pernah melakukan penelitian dengan tematema yang berkaitan. Antara lain, Kusuma (2017) mendeskripsikan tentang gerakan dakwah politik yang dilakukan oleh organisasi sayap partai nasionalis.Benny Ridwan (2016) menulis tentang respons organisasi keagamaan dan perannya dalam menciptakan harmoni umat 
beragama di Salatiga. Wattie pada hasil penelitiannya menggambarkan keterlibatan organisasi keagamaan dalam melawan HIV/AIDS di wilayah Jawa Tengah dan Bali. Sementara penelitian organisasi keagamaan di luar agama Islam juga pernal dilakukan oleh para sarjana. Antara lain, Louche (2012) menulis tentang peran serta organisasi keagamaan yang mendasari seluruh aktivitasnnya untuk meningkatkan investasi. Demikian juga Stewart (2021) menulis tentang pentingnya melibatkan organisasi keagamaan untuk melakukan kolaborasi dengan lembaga pendidikan untuk mengembangkan keterampilan siswa dalam menghadapi masa depan mereka.

Mayoritas tulisan yang dijelaskan di atas menunjukkan pentingnya peran organisasi sosial keagamaan dalam berbagai aspek kehidupan masyarakat. Organisasi keagamaan hadir sebagai kesatuan batiniah yang dapat menyatukan kepentingan yang sama setelah melalui pengalaman keagamaan yang dirasakan secara bersama-sama. Istilah Saepudin (2019) dan juga Koswara (2020), munculnya organisasasi keagamaan didasarkan kepada keyakinan, nilai dan norma yang dijunjung secara bersama-sama. Nilai yang didasarkan pada ajaran agama, dijadikan seluruh anggotanya sebagai budaya organisasi. Tulisan ini tampil dari sudut kajian yang berbeda, karena secara khusus menyajikan partisipasi organisasi keagamaan di Kota Langsa dalam penyiaran Islam. Pada bagian tulisan ini, dipaparkan secara umum kajian tentang gerakan dan formula dakwah Islam yang dirancang oleh organisasi keagamaan, sehingga dakwah yang dilakukan memiliki daya tarik.

\section{METODE PENELITIAN}

Penelitian ini dirancang dalam bentuk penelitian kualitatif yang bertujuan untuk mendeskripsikan fakta lapangan secara apa adanya. Nazir (1998) dan Mulyana (2004) pada prinsipnya menyebutkan bahwa penelitian kulitatif bertujuan mendeskripsikan kondisi ril sesuai dengan setting alamiah. Data penelitian ini dikumpulkan melalui observasi yang dilengkapi dengan wawancara, sehingga penyelidikan terhadap partisipasi dan formula dakwah yang dilakukan organisasi keagamaan dalam penyiaran dakwah di Kota Langsa terlihat secara konfrehensif. Observasi

Wawancara mendalam (in depth interview) dilakukan dengan informan kunci yang dipilih secara purposive sampling. Infoman kunci dipilih mewakili organisasi keagamaan di Kota Langsa karena merekalah yang kompeten dalam memberikan data (Bungin, 2003). Data utama yang dibutuhkan ditelusuri dengan menggunakan teknik snowball sampling, sehingga diperoleh data yang lebih utuh dan komprehensif (Huberman, 1992).

Analisis data dilakukan dalam penelitian berdasarkan petunjuk Miles dan Huberman (1992) yang dimulai dari reduksi data, display data dan penarikan kesimpulan. Keseluruhan aktivitas analisis ini dilakukan untuk mendapat gambaran dan kesimpulan yang komprehensif terhadap kegiatan dakwah organisasi keagamaan di Kota Langsa. Pendiskripsian data kedalam hasil penelitian dilakukan setelah terlebih dahulu diuji keabsahannya dengan menggunakan teknik triangulasi sumber, yaitu membandingkan antara data wawancara dengan observasi, data wawancara dengan dokumentasi (Kriyantono, 2014; Moleong, 2006).

\section{HASIL PENELITIAN DAN PEMBAHASAN}

\section{Dinamika Sosial dan Keberagamaan Masyarakat Kota Langsa}

Masyarakat Kota Langsa adalah masyarakat yang terbuka dan sangat heterogen. Keterbukaan ini didukung oleh semakin mudahnya masyarakat untuk mengakses informasi. Kota Langsa sangat strategis, karena berada di perlintasan jalan sumatera dan banyak menyediakan wisata kuliner yang dapat memanjakan para pesinggah yang melakukan perjalanan menuju Banda 
Aceh maupun Medan. Interaksi pendatang dan pribumi turut mendorong semakin tingginya mobilitas masyarakat untuk mengakses informasi yang bermanfaat bagi mereka. Setiaman (2013) menyebutkan, bahwa sikap keterbukaan masyarakat didorong oleh terjadinya peningkatan kebutuhan terhadap informasi, karena pencarinya menganggap dapat membantu dirinya menemukan ide baru, pengetahuan dan solusi terhadap persoalannya.

Mayoritas suku yang mendiami Kota Langsa adalah bersuku Aceh, dan selainnya ada suku Jawa, Tamiang, Padang, Batak Mandailing, Batak Karo dan ada juga etnis Tionghoa. Heterogenitas masyarakat Kota Langsa tidak menghalangi terjadinya interaksi sosial, karena masing-masing suku dapat saling memahami dan beradaptasi dengan situasi. Suku mayoritas tidak merasa superior, dan sebaliknya suku minoritas tidak merasa inferior. Heterogenitas penduduk turut mendorong semakin dinamisnya kehidupan masyarakat, sebagaimana misalnya yang digambarkan Andi Frank (2012) pada kehidupan migran Tanimbar di Jayapura.

Dinamisasi dan kerukunan masarakat Kota Langsa dipertunjukkan lewat kondisi nyata berdampingannya antara masjid dan gereja, antara masjid dan vihara. Penghargaan terhadap kemajemukan ini sudah sejak lama tertanam kokoh pada masyarakat Kota Langsa. Menurut pandangan penulis, kesadaran ini tidak hanya karena ada qanun yang mengatur, tetapi sadar terhadap kemajemukan adalah cerminan manusia beriman yang mengamalkan pesan Al Qur'an (QS. 49:13; QS. 4:1) dengan benar. Nurcholis Madjid (1999) menyebut, bahwa kesadaran terhadap kemajemukan menjadi satu kemestian untuk memelihara terwujudnya masyarakat religius yang demokratis. Cita-cita tersebut menjadi kehendak bersama dan bahkan harus menjadi suatu kontrak sosial yang dijalankan penuh kesadaran.

Kota Langsa sebagaimana disebut Mawardi Siregar (2019) merupakan kota kecil yang dapat dijadikan sebagai miniatur gambaran kerukunan. Meskipun fanatisme penganut agama Islam sangat tinggi terhadap ajaran Islam, tetapi dalam jangka waktu yang sudah cukup lama masyarakatnya dapat hidup berdampingan secara damai. Bahkan di Kota Langsa belum pernah terjadi konflik horizontal antarumat beragama. Masyarakat Kota Langsa sangat menjunjung tinggi nilai-nilai keagamaan, sehingga aktivitas keagamaan turut memperkuat karaktristik kota Islami yang religius.

Relasi sosial keagamaan antara masyarakatpun terjalin dengan baik. Nilai-nilai sosial kemasyarakatan ditata di atas landasan syariat Islam. Nilai-nilai tersebut berlaku dalam berbagai bentuk kegiatan, seperti pernikahan, kelahiran, kematian dan syukuran. Relasi sosial juga mewujud melalui kegiatan keagamaan yang sudah masyhur di masyarakat, seperti kenduri maulid (kenduri maulod) yang bermaksud memperingati kelahiran Nabi Muhammad Saw. Selain itu, tradisi lain yang sangat masyhur dan tidak boleh tinggal adalah tradisi mengang (makan daging) yang dilaksanakan masyarakat menjelang bulan puasa, Idul Fitri dan Idul Adha. Tradisi mengang pada masyarakat Aceh, sebagaimana yang ditulis oleh Marzuki (2014), menjadi budaya yang ditafsirkan masyarakat sebagai bagian dari ajaran agama. Tidak hanya sekedar makan daging, tetapi meugang seperti menjadi momentun menunjukkan kesalehan sosial dengan bersedekah kepada anak yatim dan fakir miskin.

Praktik musyawarah juga menjadi bahagian yang tidak terpisahkan dari masyarakat Kota Langsa. Masjid maupun meunasah yang ada di gampong (desa), tidak hanya berfugsi sebagai tempat ibadah, tetapi sekaligus menjadi tempat bermusyawarah. Berbagai persoalan diperbincangkan masyarakat dalam suasana musyawarah yang terbuka, dan setiap anggota masyarakat bebas menyampaikan aspirasinya. Namun demikian, keterbukaan dan kebebasan tidak keluar dari nilai-nilai syariat Islam. Prinsip ini menggambarkan kuatnya peletakkan dasar- 
dasar hubungan persaudaraan pada masyarakat Kota Langsa. Bahkan rasa persaudaraan tersebut sangat terlihat jelas praktiknya pada acara-acara kematian. Warga memperlihatkan kerelaan untuk meninggalkan aktivitasnya sampai seluruh fardhu kifayah terlaksana. Keinginan untuk membantu keluarga dukapun terlihat begitu tinggi. Ada masyarakat yang membantu dengan cara membawa gula, kopi, kue-kuean, dan bahan-bahan makanan pokok yang akan diberikan kembali kepaga orang yang bertakziah.

Menurut analisis saya, persaudaraan dan keinginan untuk saling tolong-menolong yang masih membumi pada masyarakat Kota Langsa, merupakan cerminan pengamalan ajaran Islam yang menukik pada subtansinya. Perintahnya sangat jelas disebutkan dalam surah $\mathrm{Al}$ Maidah ayat 2, agar tolong-menolong dalam kebaikan dan takwa. Dari perspektif teoritisnya, tolong-menolong menguatkan sikap kekitaan. Artinya, persaudaraan dan tolong-menolong melemahkan sikap egoisme dan menguatkan simpati dan empati (David G, 1996). Selain itu, sikap tolong-menolong menjadi norma masyarakat, karena ada keyakinan bahwa kalau sekarang suka menolong orang lain, suatu saat akan banyak ditolong oleh orang lain juga. Ada juga keyakinan masyarakat, bahwa menolong merupakan tanggung jawab sosial sebagai manusia, sehinga kalau sikap tolong-menolong dibudayakan, akan terciptalah keseimbangan hidup dan kedamaian.

Masyarakat Kota Langsa adalah masyarakat religius yang sangat menghargai perbedaan. Penghargaan tersebut ditunjukkan melalui sikap kesediaan hidup damai secara berdampingan dengan orang yang berbeda agama dan suku. Religiusitas masyarakat juga ditunjukkan melalui sikap keinginan untuk menjalin ukhuwah Islamiyah. Meskipun masyarakat hidup di kota, tetapi penghargaan mereka terhadap malam Jumat masih sangat tinggi. Kelompok-kelompok masyarakat yang melakukan wiritan (membaca surah yasin), membaca dalailul khoirot kerap dijumpai. Pada hari Jumat warung-warung umumnya tutup mulai pukul 12.00 WIB sampai pukul 14.00 WIB, karena masyarakat menghargai pelaksanaan shalat Jumat. Realitas ini pada prinsipnya didorong oleh kesadaran masyarakat terhadap nilai-nilai syariat Islam.

Memahami dinamika kultural, karakteristik dan keberagamaan masyarakat Kota Langsa menjadi peta konsep untuk melaksanakan dakwah tanpa pengkotak-kotakan perbedaan faham. Seperti yang dijelaskan Zulkarnain,

Sasaran dakwah itu semua orang tanpa kecuali. Hal-hal yang bersifat khilafiah sangat penting dihindarkan agar kekompakan masyarakat tetap terjaga. Organisasi keagamaan harus memosisikan dakwahnya untuk semua pihak, agar tidak berkotak-kotak. Untuk menjaga agar tidak terjadi benturan pemahaman, masyarakat harus dipahamkan. Selain itu, da'i secara perorangan maupun organisasi harus menyejukkan. Hal-hal yang sifatnya khilafiyah jangan dibesar-besarkan (Hasil Wawancara, Juli, 2017).

Dinamika sosial kemasyarakatan Kota Langsa yang banyak dilandasi motivasi keberagamaan merupakan potensi dakwah yang sangat penting dipahami. Dinamika tersebut tentu bergerak dinamis dan sewaktu-waktu akan mengalami perubahan, sesuai dengan kecenderungan masyarakat. Disinilah pentingnya peran organisasi keagamaan untuk turut menjaga agar nilai-nilai agama dan nilai-nilai sosial kemasyarakatan, tetap terkonsolidasi pada tataran praktik kehidupan sehari-hari masyarakat.

\section{Partisipasi Organisasi Keagamaan Dalam Penyiaran Dakwah di Kota Langsa}

Berorganisasi merupakan ciri khas manusia yang pada prinsipnya tidak ingin hidup menyendiri. 
Seperti yang disebutkan Goldberg (1985), bahwa pembentukan organisasi dimulai dari adanya perasaan keinginan untuk memenuhi kebutuhan yang sama, sehingga timbullah motivasi untuk membentuk kelompok. Motivasi terbentuk secara kuat berdasarkan ikatan emosional diantara individu yang ingin berinteraksi dan melakukan komunikasi dengan orang lain (Jhon \& Foos, 2013; Walgito, 2003). Thibaut dan Kelly melalui teori pertukaran sosial (social exchange theory) menjelaskan, bahwa pada prinsipnya motivasi seseorang untuk berorganisasi, tidak lain karena keinginan untuk berinteraksi dengan orang lain (Sendjaja, 1994).

Secara teoritis, pola terbentuknya organisasi keagamaan di Kota Langsa tidak berbeda dengan yang dikemukakan para pakar yang telah disebutkan di atas. Berdasarkan analisis yang dilakukan penulis, pola tersebut digambarkan sebagai berikut;

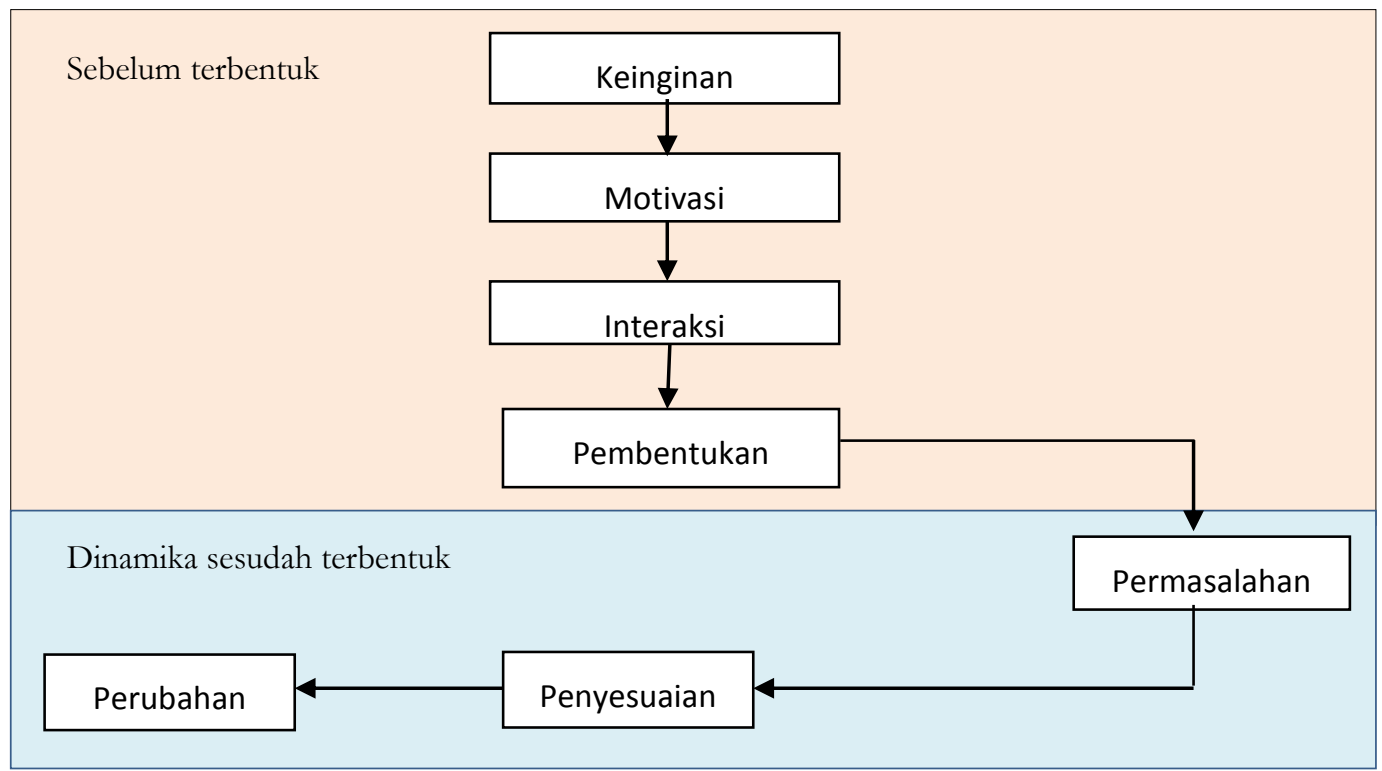

Gambar 1. Pola terbentuknya organisasi keagamaan di Kota Langsa.

Terbentuknya organisasi keagamaan di Kota Langsa dimulai dari keinginan yang sama untuk berorganisasi, sehingga muncullah motivasi membentuk organisasi. Tetapi setelah terbentuk, tidak sedikit organisasi yang mengalami stagnasi karena diterpa permasalahan internal maupun eksternal. Terlepas dari persoalan ini, penting ditegaskan bahwa divergensi organisasi keagamaan menunjukkan semakin pentingnya peran agama dalam kehidupan masyarakat. Bahkan Yudi Latif (2005) mencatat, bahwa pertumbuhan organisasi keagamaan Islam di Indonesia didorong oleh semakin kuatnya hubungan akomodasi antara Islam dan negara. Tekanan-tekanan politik terhadap Islam di masa Orde Baru, memunculkan lahirnya gagasan-gagasan besar untuk membentuk organisasi keagamaan. Transformasi strategi politik umat Islam menjelang penghujung dekade 1980-an dan awal 1990-an berimplikasi positif pada penguatan lembaga sosial keagamaan seperti Ikatan Cendikiawan Muslim Indonesia (ICMI) dan Majelis Ulama Indonesia (MUI), dan lain-lain.

Berdasarkan fakta tersebut, maka munculnya sejumlah organisasi keagamaan diberbagai daerah merupakan perwujudan aspirasi umat Islam. Menurut catatan penulis, di Kota Langsa terdapat sejumlah organisasi keagamaan yang dijadikan masyarakat sebagai forum aspirasi, menjalin komunikasi dan interaksi sekaligus pembinaan spritual. Organisasi keagamaan tersebut berdiri atas dasar keinginan bersama, motivasi dan semangat keagamaan. Tujuannya, selain ingin berpartisipasi dalam mendakwahkan ajaran Islam, organisasi keagamaan sekaligus ingin mengambil peran dalam mengatasi persoalan ekonomi, pendidikan, moralitas, penegakan 
syariat dan lingkungan hidup. Masing-masing organisasi keagamaan memiliki karakteristik yang menjadi prinsip gerakan dakwahnya. Keberadaan organisasi kegamaan di Kota Langsa, dapat dilihat pada tabel berikut.

Tabel 1. Karakteristik organisasi keagamaan di Kota Langsa

\begin{tabular}{|c|c|c|c|}
\hline No & Nama Organisasi & Karakteristik dakwah & Aktor utamanya \\
\hline 1 & $\mathrm{NU}$ & Moderat dan dinamis. & Kolaborasi antara Akademisi \\
\hline 2 & Muhammadiyah & Tajdid (pembaharuan) & Akademisi \\
\hline 3 & Al Wasliyah & Moderat dan kultural & Akademisi \\
\hline 4 & MPU & Struktural dan kultural & Tokoh agama \\
\hline 5 & $\begin{array}{l}\text { IKADI (Ikatan Da'i } \\
\text { Indonesia) }\end{array}$ & Progresif & Akademisi \\
\hline 6 & $\begin{array}{l}\text { Dewan Dakwah Islam } \\
\text { Indonesia (DDII) }\end{array}$ & Moderat & Akademisi \\
\hline 7 & ICMI & Moderat, logis, rasional & Akademisi \\
\hline 8 & BKPRMI & Dakwah struktural & Aktivis pemuda \\
\hline 9 & IPHI & Dakwah kultural & Tokoh masyarakat \\
\hline 10 & Majelis Al Maidah & Dakwah kultural & Tengku dayah \\
\hline 11 & TASTAFI & Dakwah kultural & Tengku dayah \\
\hline 12 & Assunni & Dakwah kultural & Tengku dayah \\
\hline 13 & HUDA & Dakwah kultural & Tengku dayah \\
\hline
\end{tabular}

Organisasi keagamaan yang disebutkan di atas dapat dikategorikan kepada organisasi keagamaan yang terorganisir. Misalnya NU, Muhammadiyah dan Al Washliyah, ICMI, MPU merupakan organisasi yang sudah ada sejak masa waktu yang cukup lama, dan terorganisir dengan rapi. Selain itu, organisasi di atas muncul karena adanya kesadaran komunal, baik karena kesamaan minat, keahlian dan profesi, seperti IKADI, BKPRMI, IPHI. Organisasi keagamaan lainnya muncul karena sikap eksklusif yang sering disebut dengan aliran sempalan dalam Islam yang membangun satu komunitas tersendiri secara sukarela. Komunitas tersebut muncul karena adanya keinginan yang sama untuk memahami dan mengamalkan agama dengan cara yang amat khas, seperti Majelis Al Maidah, Assuni, TASTAFI, dan HUDA.

Latar belakang berdirinya organisasi keagamaan tersebut, turut menjadi pembeda gerakan dakwah yang dilakukan di masyarakat. Misalnya, Majelis Al Maidah, Majelis Assuni, TASTAFI, dan HUDA lebih mengedepankan dakwah kultural yang sentra gerakan dakwahnya berpusat di masjid dan majelis-majelis taklim, karena para pendirinya adalah ulama-ulama dayah. Berbeda dengan NU, Muhammadiyah, Al Wasliyah, ICMI, DDII dan MPU yang dimotori oleh para akademisi dan juga tokoh masyarakat, lebih mengedepankan dakwah struktural. Selain berpusat di masjid, gerakan dakwahnya turut mempengaruhi kebijakankebijakan di tingkat pemerintahan, sehingga dakwahnya lebih bersifat politis. Dakwah politik sebagaimana ditulis oleh Andi Rosa (2014) sering juga dimanfaatkan para aktornya untuk melanggengkan tujuan politik sesuai dengan kepentingan kelompoknya.

Kehadiran organisasi keagamaan di Kota Langsa mendapat respons positif dari pemerintah dan masyarakat. Pemerintah merasa kehadiran organisasi keagamaan dapat menjadi mitra dalam menuntaskan permasalahan yang dihadapi pemerintah. Masyarakat merasa, bahwa 
kehadiran organisasi keagamaan tidak hanya sebagai wadah aspirasi, tetapi sekaligus wadah pembinaan dan sekaligus instrumen pendukung semaraknya kegiatan penyiaran dakwah Islam. Berdasarkan analisis penulis, wujud partisipasi organisasi kegamaan di kota Langsa dapat klasifikasikan kepada empat kegiatan.

\section{Partisipasi Dalam Penguatan Syariat Islam}

Kota Langsa merupakan kota syariat. Dalam kegiatan-kegiatan formal maupun nonformal, penegakan syariat Islam tetap menjadi isu-isu penting yang diusung oleh organissi keagamaan. Menurut analisis penulis, ada beberapa alasan penegakan syariat menjadi isu penting yang terus digelorakan oleh organisasi keagamaan di Kota Langsa. Pertama, bentuk dukungan terhadap program pemerintah dalam mewujudkan visi misi Kota Langsa sebagai kota jasa yang maju dan Islami. Bagaimanapun, harus diakui bahwa hubungan antara pemerintah dengan organisasi keagamaan di Kota Langsa relatif harmonis. Harmoni tersebut mewujud pada kesertaan organisasi keaamaan dalam menginisiasi kegiatan-kegiatan keislaman yang disponsori oleh Pemerintah Kota Langsa dan organisasi keagamaan, seperti tablig akbar, zikir akbar menyambut pergantian tahun baru. Kedua, Kota Langsa adalah kota percontohan dalam penegakan syaraiat Islam. Organisasi keagamaan ingin menampilkan dirinya sebagai bagian dari elemen masyarakat yang turut berpartisipasi aktif dalam mempertahankan prestasi tersebut. Sikap tersebut mewujud pada keikutsertaan dalam melakukan razia tempat hiburan, judi dan pelaku mesum. Ketiga, masyarakat Kota Langsa sangat majemuk. Organisasi keagamaan menampilkan diri sebagai salah satu pilar untuk memelihara tegaknya kerukunan di tengah kemajemukan. Sikap tersebut mewujud pada kesertaan dalam dialong antarumat beragama, dan pengamanan terhadap kebaktian umat Kristiani. Keempat, Kota Langsa adalah kota wisata yang termasuk banyak didatangi oleh wisatawan dari dalam maupun dari luar Aceh. Sebagai kota wisata, tentu asimilasi antara budaya luar dengan budaya lokal tidak dapat dihindari. Bisa jadi budaya lokal tercerabut dari akarnya, karena derasnya serbuan budaya luar. Mengantisipasi kondisi tersebut, organisasi keagamaan tampil dalam mengawal moralitas masyarakat. Sikap tersebut mewujud pada kesertaan dalam memberikan program-program pembinaan rutin bagi remaja dan orang tua yang dilakukan di masjid, di mushalla, dan majelis taklim.

\section{Partisipasi Meningkatkan Wawasan Pengetahuan Agama}

Organisasi keagamaan berpartisipasi aktif dalam meningkatkan pengetahuan agama. Tidak hanya bagi pengurus dan anggotanya, tetapi meluas sampai kelapisan masyarakat umum. Beberapa kegiatan yang umum dilakukan dalam konteks ini adalah dengan menyemarakkan secara rutin kajian-kajian keagamaan. Organisasi keagamaan yang dimotori oleh aktor-aktor berlatar belakang dayah (Assunni, TASTAFI, Al Maidah, HUDA, MPU), secara umum memiliki pengajian di masjid-masjid dan juga majelis taklim di rumah-rumah warga. Pengajian terbuka untuk umum dengan tema-tema keagamaan yang dilandaskan pada kajian kitab-kita klasik. Bagi organisasi keagamaan yang dimotori oleh aktor-aktor berlatar belakang akademisi (NU, Muhammadiyah, Al Washliyah, ICMI dan DDII), peningkatan pengetahuan agama lebih cederung dilakukan melalui kegiatan seminar, workshop dan diskusi-diskusi ilmiah lainnya. Kegiatan umumnya terfokus di kampus dan juga tempat-tempat resmi lainnya, seperti hotel, aula dan gedung serba guna. Sedangkan organisasi keagamaan yang dimotori oleh aktivis pemuda, seperti BKPRMI, IKADI cenderung melakukan peningkatan pengetahuan agama melalui perkaderan-perkaderan yang terfokus di masjid.

\section{Partisipasi Meningkatkan Wawasan Pengetahuan Agama}

Organisasi keagamaan berpartisipasi aktif dalam meningkatkan pengetahuan agama. Tidak hanya bagi pengurus dan anggotanya, tetapi meluas sampai kelapisan masyarakat umum. Beberapa kegiatan yang umum dilakukan dalam konteks ini adalah dengan menyemarakkan 
secara rutin kajian-kajian keagamaan. Organisasi keagamaan yang dimotori oleh aktor-aktor berlatar belakang dayah (Assunni, TASTAFI, Al Maidah, HUDA, MPU), secara umum memiliki pengajian di masjid-masjid dan juga majelis taklim di rumah-rumah warga. Pengajian terbuka untuk umum dengan tema-tema keagamaan yang dilandaskan pada kajian kitab-kita klasik. Bagi organisasi keagamaan yang dimotori oleh aktor-aktor berlatar belakang akademisi (NU, Muhammadiyah, Al Washliyah, ICMI dan DDII), peningkatan pengetahuan agama lebih cederung dilakukan melalui kegiatan seminar, workshop dan diskusi-diskusi ilmiah lainnya. Kegiatan umumnya terfokus di kampus dan juga tempat-tempat resmi lainnya, seperti hotel, aula dan gedung serba guna. Sedangkan organisasi keagamaan yang dimotori oleh aktivis pemuda, seperti BKPRMI, IKADI cenderung melakukan peningkatan pengetahuan agama melalui perkaderan-perkaderan yang terfokus di masjid.

\section{Partisipasi dalam Penguatan Silaturahmi}

Organisasi keagamaan turut berpartisipasi dalam penguatan silaturahmi antara sesama anggota dan juga masyarakat umum. Silaturahmi merupakan proses pengumpulan keuntungan duniawi dan ukhrawi, baik secara individual maupun kolektif. Silaturahmi memanjangkan umur, menambah pengalaman dan pengetahuan. Silaturahmi membuat seseorang menjadi pendidik dan lebih terdidik, memberi dan menerima kedamaian (Al Ghazali, 1990). Ajaran doktrin keagamaan inilah yang ditanamkan oleh organisasi keagamaan kepada anggota maupun kepada masyarakat umum. Penguatan silaturahmi ini mewujud dalam gerakan dakwah keseharian, sebagaimana yang dilakukan oleh Ikatan Persaudaraan Haji Indonesia (IPHI) Kota Langsa. Untuk menguatkan silaturahmi sesama masyarakat, organisasi ini melakukan kajian-kajian keagamaan dengan cara berpindah-pindah dari satu masjid ke masjid lain.

\section{Partisipasi dalam Pembinaan Moralitas Remaja}

Organisasi keagamaan berpartisipasi aktif dalam pembinaan moralitas remaja Kota Langsa. Pembinaan dilakukan melalui organisasi-organisasi remaja masjid, perkumpulan pemuda gampong (desa). Kegiatan dilakukan sebagai bentuk preventif terhadap serbuan budaya luar yang masuk ke tengah-tengah masyarakat, baik langsung maupun tidak langsung. Secara langsung adalah efek yang terjadi dari terjadinya asimilasi budaya luaran dengan lokal, sedangkan tidak langsung adalah budaya yang masuk melalui penyebaran media informasi. Pembinaan dilakukan sebagai upaya untuk menanamkan moralitas Islam dan ke-Acehan yang senantiasa didasarkan pada ajaran Islam.

\section{Partisipasi dalam pembinaan da'i dan da'iyah}

Organisasi keagamaan berpartisipasi dalam membina sumber daya da'i dan da'iyah. Organisasi keagamaan yang cenderung melakukan pembinaan da’i adalah Majelis Permusyawaratan Ulama (MPU). Pembinaan dilakukan untuk meningkatkan kompetensi da’i secara subtansi maupun metodologisnya, sehingga lebih profesional dalam melaksanakan tugas dakwah. Menurut analisis yang dilakukan, pembinaan da'i dilakukan rutin oleh MPU karena masih banyak da'i yang memandang kegiatan dakwah hanya rutinitas menyampaikan ajaran Islam melalui ceramah. Senyatanya, mayoritas da'i Kota Langsa umumnya cenderung menggunakan metode ceramah (bil lisan) dalam menyampaikan dakwah. Padahal masih ada metode lain yang lebih menarik digunakan untuk berdakwah, seperti melalui tulisan (bil kitabah) dan tindakan nyata (bil hal). Dakwah melalui tulisan (bil kitabah) sifatnya lebih praktis dan jangkauannya lebih luas, sedangkan dakwah pemberdayaan (bil hal) seperti pemberdayaan ekonomi lebih terasakan manfaatnya oleh masyarakat. Namun demikian, masih jarang ditemukan aktivitas dakwah yang 
dilakukan da'i melalui tulisan (bil kitabah) dan tindakan (bil hal). Kondisi ini terjadi karena kemampuan menulis para da'i yang masih terbatas dan sudah merasa nyaman dengan metode dakwah berceramah (bil lisan).

Beberapa kegiatan yang dijelaskan, merupakan wujud partisipasi organisasi keagamaan dalam penyiaran dakwah Islam di Kota Langsa. Namun sangat penting untuk ditegaskan, bahwa partisipasi organisasi keagamaan belum banyak memberikan kontribusi terhadap persoalan masyarakat. Ada organisasi keagamaan yang hanya namanya saja dan aktivitasnya hampir tidak ditemukan. Alih-alih untuk menggelorakan dakwah pemberdayaan ekonomi, sosial, pendidikan dan lingkungan hidup, menggelorakan dakwah Islam secara organisatorispun hampir tidak terasakan. Bahkan ada kegiatan beberapa organisasi yang bersifat monoton dan musiman. Misalnya ada organisasi yang muncul hanya pada saat peringatan Maulid Nabi, Isra' Mi'raj, dan Safari Ramadhan. Padahal, dakwah tidak hanya pada hari-hari besar tersebut. Kegiatan dakwah harus mempertimbangkan tujuan yang lebih luas, sehingga mampu membentuk perilaku sosial masyarakat kearah yang lebih produktif (Siregar, 2013).

Menurut analisis saya, ada tiga faktor yang menyebabkan terjadinya kondisi tidak dinamisnya kegiatan dakwah yang dilakukan organisasi keagamaan di Kota Langsa. Pertama, disebabkan SDM pengelola organisasi yang masih rendah. SDM tidak hanya berkaitan dengan latar belakang pendidikan, pengalaman dan kepemimpinan. SDM juga mencakup pada keseriusan, komitmen dan loyalitas untuk menjalankan job description (pembagian kerja), visi dan misi organisasi. Kedua, kesenjangan komunikasi diantara sesama lini dalam organisasi. Morissan (2013) menyebut bahwa prinsip dasar berorganisasi dimulai dari proses komunikasi. Tetapi secara realitas terlihat, iklim komunikasi pada sejumlah organisasi keagamaan tidak terkelola dengan baik. Ketiga, budaya organisasi yang belum tertanam dalam diri pengurusnya. Budaya organisasi adalah keseluruhan norma dan nilai dominan yang dijadikan secara bersama-sama untuk mengerakkan berjalannya roda organisasi (Jhon \& Foos, 2013; Morissan, 2013).

Mencerdasi faktor yang disebutkan, organisasi keagamaan amat sangat penting melakukan reorientasi tujuan pembentukan organisasi. Selain itu, penguatan visi, misi dan juga tujuanpun perlu direvitalisasi, agar organisasi keagamaan lebih fungsional dalam mewujudkan tujuannya. Terutama jika dikaitkan dengan dinamika masyarakat Kota Langsa yang terus bergerak, tentu harus disadari bahwa dinamika tersebut akan berimplikasi pada pilihan gerakan dakwah yang akan dilakukan. Sejalan dengan tingginya tingkat kebutuhan masyarakat dalam memperolah informasi, maka organisasi keagamaan di Kota Langsa harus dapat mengimbanginya dengan meningkatkan kualitas SDM dan menata manajemen organisasi dengan baik, sehingga gerakan dakwahnya lebih luas dan lebih terukur.

Perubahan masyarakat menjadi tantangan sekaligus tuntutan bagi organisasi dakwah yang ada di Kota Langsa, agar melakukan aktivitas dakwahnya secara profesional. Pengurus organisasi keagamaan perlu mengemas dakwah sesuai dengan kebutuhan masyarakat, sehingga dakwah yang dilakukan lebih solutif dalam menjawab persoalan umat. Amrullah Ahmad (1983) menyebutkan, ada tiga tahapan yang dapat dilakukan untuk merumuskan dakwah solutif dan memberdayakan umat, yaitu takwin, tanæim dan ta'udi. Takwin adalah mendakwahi masyarakat dengan tema-tema akidah, yang dimulai dari keluarga sampai ke lingkungan yang lebih besar. Tanæim adalah menginternalisasikan nilai-nilai Islam sehingga menjadi karakteristik masyarakat. 
Sedangkan taudi' adalah memberdayakan masyarakat sehingga menjadi lebih mandiri dan terlepas dari ketergantungan.

Mengaitkan pandangan Amrullah Achmad dengan realitas dakwah organisasi keagamaan di Kota Langsa, ada empat model dakwah yang ditawarkan agar dakwah melalui organisasi lebih fungsional. Pertama, dakwah yang dilakukan harus lebih berorientasi kepada misi kerahmatan. Subtansi ajaran Islam tidak hanya dibicarakan pada tataran pencapaian tujuan akhirat, tetapi kesejahteraan duniapun sangat penting di dakwahkan. Jika ini yang dilakukan, maka membicarakan Islam tidak cukup di masjid dan dakwah tidak lagi berbicara ibadah saja. Kedua, dakwah dapat dilakukan sesuai kondisi. Misalnya, masyarakat Aceh sangat gemar memperingati maulid Nabi Muhammad Saw. Tentu kondisi ini dapat dijadikan sebagai momentum untuk penguatan ajaran Islam yang sejalan dengan visi misi organisasi. Organsasiorganisasi dakwah dapat mensiponsori pelaksanaannya. Ketiga, dakwah aktual seperti membicarakan persoalan-persoalan kemasyarakatan yang sifatnya aktual dan bersentuhan langsung dengan masyarakat setempat. Keempat, model dakwah yang inklusif, moderat dan populis. Kehadiran organisasi keagamaan harus berkontribusi bagi seluruh lapisan masyarakat, baik yang menjadi anggota organisasi maupun yang bukan anggota organisasi.

Dengan memahami keempat model dakwah yang ditawarkan di atas, masyarakat Kota Langsa akan lebih optimis lagi dalam menilai kehadiran organisasi keagamaan. Selain itu, masyarakat akan menaruh kepercayaan, bahwa dakwah yang dilakukan organisasi keagamaan mampu memberikan solusi terhadap persoalan mereka. Sebaliknya, organisasi keagamaanpun akan mampu memaksimalkan dakwahnya, tidak hanya dalam membatu masyarakat keluar dari persoalan keagamaan (ibadah), tetapi sekaligus persoalan sosial, ekonomi, politik, pendidikan dan aspek lainnya.

\section{PENUTUP}

Organisasi keagamaan di Kota Langsa menjalankan perannya sebagai wadah penyiaran dakwah Islam, tidak hanya bagi anggotanya tetapi sekaligus bagi masyarakat luas. Organisasi keagamaan berpartisipasi aktif dalam penguatan syariat Islam, meningkatkan wawasan dan pengetahuan agama masyarakat, berpartisipasi dalam memberikan pembinaan moral bagi remaja, menguatkan hubungan silaturahmi dan berpartisipasi dalam melakukan pembinaan da'i dan da'iyah. Namun partisipasi penyiaran dakwah Islam yang dilakukan belum terasakan maksimal oleh masyarakat, karena dakwah yang dilakukan masih bersifat monoton dan musiman. Untuk mengatasi kondisi ini, organisasi keagamaan di Kota Langsa perlu mengemas dakwah yang berorientasi sesuai dengan konteks masyarakat. Organisasi keagamaan juga sangat penting merancang formula dakwah yang relevan dengan kecenderungan masyarakat, agar dakwah yang dilakukan memiliki daya tarik dalam memberdayakan potensi keagamaan masyarakat.

\section{DAFTAR PUSTAKA}

Abdul, M. (2001). Komunikasi Islam. Bandung: PT. Remaja Rosdakarya.

Achmad, A. (1983). Dakwah Islam dan Perubahan Sosial. Yogyakarta: Prima Duta.

Al Ghazali, I. (1990). Ibya Ulumuddin (2nd ed.; Z. Muhammad, trans.). Semarang: Asy-Syifa.

Bungin, B. (2003). Analisa Data Penelitian Kualitatif: Pemahaman Filosofis ke Arab Penguasaan Model Aplikasi. Jakarta: PT RajaGrafindo Persada.

David G, M. (1996). Social Psychologi. New York: Mc Graw-Hill International. 
Frank, A. (2012). Proses Mobilitas dan Strategi adaptasi Orang Tanibar Di Kota Jayapura, Propinsi Papua. Humaniora, 16(2), 168-176. https://doi.org/10.22146/JH.816

Gerald M, G., \& Carl E, L. (1985). Komunikasi Kelompok; Proses-Proses Diskusi dan Penerapannya (S. Koedarini \& J. Gary R, trans.). Jakarta: UI Press.

Hasil Wawancara, Juli. (2017). Langsa.

Hoover, S. M. (2021). Mediations of Religion and Politics as "Affective Infrastructures": A Cross-Disciplinary Reflection on Contemporary Politics. International Journal of Communication, 15, 3139-3153. Retrieved from https://ijoc.org/index.php/ijoc/article/view/17149

Huberman, M. B. M. dan A. M. (1992). Analisis Data Kualitatif (T. R. Rohidi, trans.). Jakarta: UI Press.

Jalaluddin, R. (2001). Psikologi Komunikasi. Bandung: PT. Remaja Rosdakarya.

Jhon, S. W. L., \& Foos, K. A. (2013). Teori Komunikasi (M. Y. Hamdan, trans.). Jakarta: Salemba Humanika.

Kholil, S. (2007). Komunikasi Islam. Bandung: Cita Pustaka.

Koswara, I. (2020). Da'wah Organization Development Strategy Through Organizational Culture. Ilmu Dakwah: Academic Journal for Homiletic Studies, 14(1). https://doi.org/10.15575/idajhs.v14i1.8830

Kriyantono, R. (2014). Teknik Praktis Riset Komunikasi (7th ed.). Jakarta: Kencana Prenada Media.

Kusuma, B. M. A., \& Octastefani, T. (2017). Negosiasi Dakwah Dan Politik Praktis (Membaca Orientasi Organisasi Sayap Keagamaan Islam Pada Partai Nasionalis). Al-Balagh: Jurnal Dakwah Dan Komunikasi, 2(1). https://doi.org/10.22515/balagh.v2i1.690

Latif, Y. (2005). Inteligensia Muslim dan Kuasa: Genealogi Inteligensia Muslim Indonesia Abad Ke-20. Bandung: Mizan.

Louche, C., Arenas, D., \& van Cranenburgh, K. C. (2012). From Preaching to Investing: Attitudes of Religious Organisations Towards Responsible Investment. Journal of Business Ethics, 110(3). https://doi.org/10.1007/s10551-011-1155-8

Marzuki, M. (2014). Tradisi Meugang dalam Masyarakat Aceh: Sebuah Tafsir Agama dalam Budaya. El-HARAKAH, 16(2), 216. https://doi.org/10.18860/EL.V16I2.2781

Moh, N. (1998). Metode Penelitian. Jakarta: Ghalia Indonesia.

Moleong, L. J. (2006). Metode Penelitian Kualitatif. Bandung: PT. Remaja Rosdakarya.

Morissan. (2013). Teori Komunikasi: Individu Hingga Massa Edisi Pertama. Jakarta: Kencana.

Mulyana, D. (2004). Metode Penelitian Kualitatif: Paradigma baru Ilmu Komunikasi dan Ilmu Sosial Lainnya. Bandung: Remaja Rosdakarya.

Nurcholish, M. (1999). Cita-Cita Politik Islam Era Reformasi. Jakarta: Paramadina.

Ridwan, B. (2016). Potret Organisasi Keagamaan Dan Respon Terhadap Dinamika Kehidupan Keberagamaan di Salatiga. INFERENSI, 5(1). https://doi.org/10.18326/infsl3.v5i1.101120

Rosa, A. (2014). Politik Dakwah Dan Dakwah Politik di Era Reformasi Indonesia. Walisongo: Jurnal Penelitian Sosial Keagamaan, 22(1), 57-82. https://doi.org/10.21580/WS.22.1.259 
Saepudin, J. (2019). Majelis Percikan Iman: Membangun Harmoni di Tengah Heterogenitas Organisasi Keagamaan Kota Bandung. Jurnal Bimas Islam, 12(1). https://doi.org/10.37302/jbi.v12i1.76

Sendjaja, S. D. (1994). Teori Komunikasi. Jakarta: Universitas Terbuka.

Setiaman, A., Sugiana, D., \& Mahameruaji, J. N. (2013). Implementasi Kebijakan Keterbukaan Informasi Publik. Jurnal Kajian Komunikasi, 1(2), 196-205. https://doi.org/10.24198/JKK.V1I2.6044

Siregar, M. (2013). Mendakwahi Orang-Orang Yang Sudah Percaya: Pembentukan Perilaku Sosial Masyarakat Nelayan Pesisir Kuala Langsa Propinsi Aceh. Jurnal Dakwah, 14(1), 133-155. https://doi.org/10.14421/JD.2013.14106

Siregar, M. (2019). Perencanaan Komunikasi Pemerintah Kota Langsa Dalam Membangun Kota Yang Islami Dan Ramah Lingkungan. Disertasi UIN SU.

Suprayogo, I. (2008). Telaah Peran Organisasi Keagamaan Dalam Pengembangan Pendidikan, Sosial, dan Dakwah. El-HARAKAH, 5(2). https://doi.org/10.18860/el.v3i2.5138

Walgito, B. (2003). Pengantar Psikologi Umum. Yogyakarta: Andi Offset. 